\title{
WNT9A wt Allele
}

National Cancer Institute

\section{Source}

National Cancer Institute. WNT9A wt Allele. NCI Thesaurus. Code C52984.

Human WNT 9A wild-type allele is located in the vicinity of $1 q 42$ and is approximately 29

$\mathrm{kb}$ in length. This allele, which encodes protein wnt-9a, may play a role in the development of embryonic tissue. 